\title{
Barriers to the adoption of photovoltaic systems: The state of the art
}

\author{
Emrah Karakaya ${ }^{\mathrm{a}, \mathrm{b}, 1}$, Pranpreya Sriwannawit ${ }^{\mathrm{a}, *, 1}$ \\ a Department of Industrial Economics and Management, KTH Royal Institute of Technology, Sweden \\ ${ }^{\mathrm{b}}$ Department of Industrial Engineering, Business Administration and Statistics, Universidad Politecnica de Madrid, Spain
}

\section{A R T I C L E I N F O}

\section{Article history:}

Received 11 July 2014

Accepted 20 April 2015

\section{Keywords:}

Diffusion

Innovation

Renewable

Solar energy

Solar home system

\begin{abstract}
A B S T R A C T
Although photovoltaic (PV) systems have become much more competitive, the diffusion of PV systems still remains low in comparison to conventional energy sources. What are the current barriers hindering the diffusion of PV systems? In order to address this, we conducted an extensive and systematic literature review based on the Web of Science database. Our state-of-the-art review shows that, despite the rapid development and maturity of the technology during the past few years, the adoption of PV systems still faces several barriers. The wide adoption of PV systems-either as a substitute for other electricity power generation systems in urban areas or for rural electrification-is a challenging process. Our results show that the barriers are evident for both low- and high-income economies, encompassing four dimensions: sociotechnical, management, economic, and policy. Although the barriers vary across context, the lessons learned from one study can be valuable to others. The involvement of all stakeholders-adopters, local communities, firms, international organizations, financial institutions, and government-is crucial to foster the adoption.
\end{abstract}

(c) 2015 Elsevier Ltd. All rights reserved.

\section{Contents}

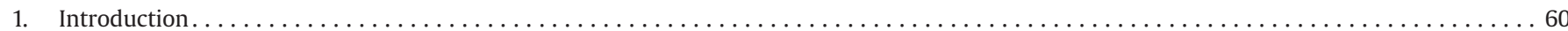

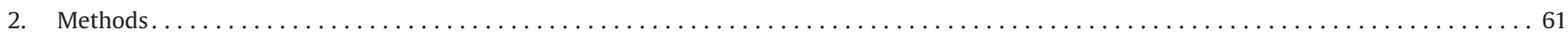

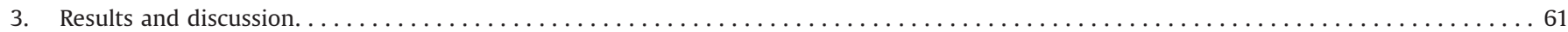

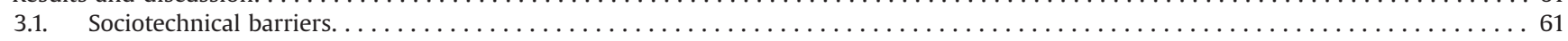

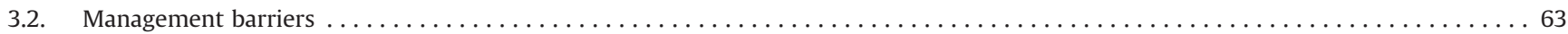

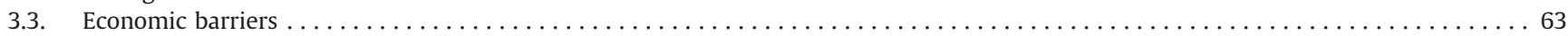

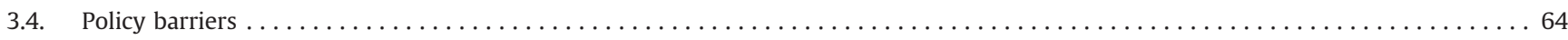

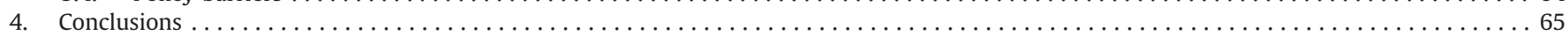

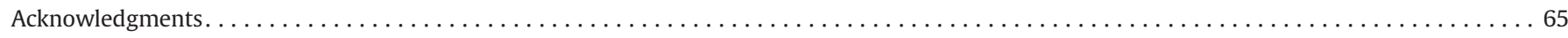

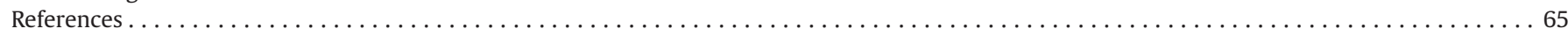

\section{Introduction}

Electricity has become the preferred type of energy in the modern world [1]. The demand for electricity has rapidly grown globally. At the same time, there are still 1.3 billion people living without electricity [2]. The production of electricity should, however, be shifted from conventional energy sources to renewable

\footnotetext{
*Corresponding author. Tel.: +468 7908735 .

E-mail address: pranpreya.sriwannawit@indek.kth.se (P. Sriwannawit).

${ }^{1}$ Both authors made equal contributions.
}

sources because of the environmental impact and depletion of fossil fuel reserves. Generating electricity from solar energy, an abundant and renewable source, using photovoltaic (PV) systems is one means. However, even in the most developed PV market, which is Europe, only 3\% of the electricity mix is generated from PV systems [3]. The global PV market represents a heterogeneous countryshare. For example, Germany has 35,500 MW installed capacity; China, 18,300 MW; the US, 12,022 MW; Australia, 3,255 MW; and Thailand $704 \mathrm{MW}$ [4]. Some countries have much lower installed capacity and often measured by the number of small-size installations, for example, Uganda, 30,000 systems [5]; and Bangladesh, 3 million systems (equal to about $135 \mathrm{MW}$ ) [6]. 
Diffusion research on PV systems has existed since the 1980s with a growing interest (e.g., [7-9]). Many scholars have studied this phenomenon from a sociotechnical perspective (e.g., [10,11]). Some researchers have focused on economic aspects (e.g., [12,13]), while others have analyzed policy (e.g., $[14,15]$ ) and management dimensions (e.g., [16,17]). Many empirical studies have appeared in different contexts, not only based on a variety of countries, for example, Germany [15], Zimbabwe [18], and Thailand [17], but also type of application, for example, on-grid (e.g., $[19,20])$ and off-grid systems (e.g., $[21,22])$. For several decades, technology and costs were assumed to be not commercially competitive compared with conventional energy sources (see e.g., [23]). Recently, PV systems have become more competitive because of the maturity of the technology [24] and declining production costs [25]. However, the adoption of PV systems remains very low compared with conventional energy sources [26]. What are the barriers hindering the adoption of PV systems?

Studying barriers has been of common interest in many fields (e.g., $[27,28])$, including renewable energy research (e.g., $[23,29,30])$. However, there is no comprehensive and recent study on barriers to the adoption of PV systems. Filling this gap, the aim of this article is to investigate the barriers to the adoption of PV systems in a variety of contexts. To address this, we conducted an extensive and systematic literature review based on the Web of Science database by focusing on the adoption of PV systems by household adopters.

The rest of the paper has three sections. Our methodological steps are elaborated in Section 2. In Section 3, we discuss our findings, categorizing the barriers into four dimensions: sociotechnical, economic, management, and policy. Finally, the conclusions are presented in Section 4.

\section{Methods}

In this study, we have conducted a systematic literature review that is based on a transparent four-step process (see Fig. 1). To retrieve publications, we have used the Social Sciences Citation Index (SSCI) of the Web of Science Core Collection, which is a commonly used database for review studies (e.g., [31,32]). For the first step, we identified a combination of keywords as follows: (diffus* OR adopt*) AND (photovolt* OR PV OR SHS* OR "solar home system $^{*}$ "). This set of keywords was searched in the abstracts, titles, and keywords of the publications from the SSCI from 2011 to 2013, yielding 103 publications. The term adoption has been included because it is often used as a synonym to diffusion (e.g., $[33,34])$. In addition, we have also included the term solar home system and its acronym SHS because PV systems are sometimes referred to as solar home systems, especially in rural contexts. ${ }^{2}$

In the second step, we evaluated each publication for its relevance to the adoption of PV systems by individuals, based on the abstracts, titles, and keywords. If a publication has relevance, it is eligible for inclusion in the third step. This resulted in 73 full texts. In the third step, we evaluated the full texts in detail for their relevance to the barriers to PV adoption by households. This ensures we do not miss any relevant information from the publications. If a study addresses any kind of barrier to the diffusion, it is included for analysis in the fourth step. As a result,

\footnotetext{
${ }^{2}$ Our analysis focuses on the most recent studies because we aim to provide state-of-the-art results. By doing this, the implications can be applied to the current debate on how to increase universal access to sustainable energy. If we expanded our time span to 1975-2013 (instead of 2011-2013) the total counts of publications from the first and second steps would be 175 and 122, respectively (instead of 103 and 73). This means that more than half of the relevant publications are from 2011 to 2013. This implies that the topic regarding the barriers to adoption has received more attention from academia recently.
}

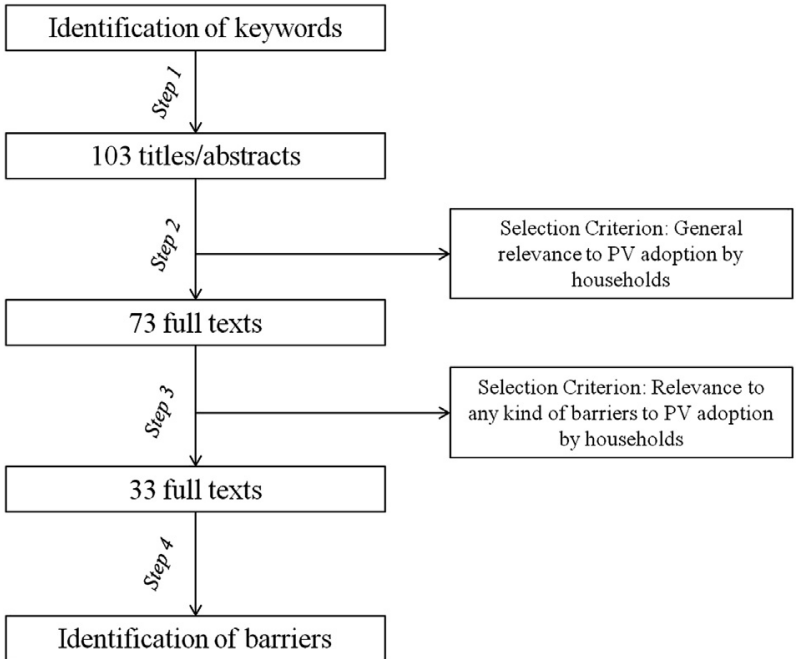

Fig. 1. Flow chart of the research process.

this left us with 33 full texts for the identification of barriers. Finally, as the fourth step, we analyzed the barriers in four dimensions-sociotechnical, economic, management, and policywith some additional references to previous research in order to render clearer understanding.

\section{Results and discussion}

The review of the selected 33 publications covers 28 countries from four continents: Africa, Asia, Europe, and America. These countries also represent all ranges of income levels according to the World Bank definition [35]. Table 1 summarizes the publications by country. Based on the analysis of selected publications, we have analyzed the barriers in four dimensions: sociotechnical, management, economic, and policy. As is widely known in diffusion literature (e.g., [34]), the adoption of innovations, such as renewable energy technologies, is a complex process with several connected factors. Therefore, the dimensions of these barriers are also interrelated and our categorization does not aim at a rigid taxonomy.

\subsection{Sociotechnical barriers}

Although PV technology has advanced tremendously in the last decades [24], many of the selected publications show that there are still several sociotechnical barriers to adoption.

The quality of PV systems is of vital importance for adoption. It can be influenced by not only the local conditions of the user's environment [10] but also the political and financial arrangements [21] that may change from country to country. A concrete example of such a phenomenon is given by Palit [21]. He mentions that Bangladesh and India have better quality standards for PV systems, especially for battery performance, than Sri Lanka. In China, there is a high level of dissatisfaction with the low performance of SHS. Although such performance may be caused by not only technical functionality but also improper usage, the dissatisfaction works against other potential adopters purchasing PV systems. In addition, damaged PV systems were common, which is partly due to having repair locations too far from the adopters [45]. In Ethiopia, there is growing skepticism toward products manufactured in Asia, especially those from China. Customers mistrust the goods and do not want to purchase them. Instead, they prefer other products, even with a higher price [10]. 
Table 1

Overview of 33 publications by country. ${ }^{3}$

\begin{tabular}{|c|c|c|}
\hline Category & Country & Studied by \\
\hline Low-income economies & $\begin{array}{l}\text { Bangladesh } \\
\text { Cambodia } \\
\text { Ethiopia } \\
\text { Kenya } \\
\text { Nepal } \\
\text { Tanzania } \\
\text { Zimbabwe }\end{array}$ & $\begin{array}{l}{[21,36,37]} \\
{[36]} \\
{[10,36]} \\
{[36,38-40]} \\
{[21,41]} \\
{[36,38]} \\
{[39]}\end{array}$ \\
\hline Lower-middle-income economies & $\begin{array}{l}\text { Bolivia } \\
\text { Ghana } \\
\text { India } \\
\text { Indonesia } \\
\text { Lao PDR } \\
\text { Nicaragua } \\
\text { Senegal } \\
\text { Sri Lanka }\end{array}$ & $\begin{array}{l}{[42]} \\
{[36,39]} \\
{[21,36]} \\
{[12,36]} \\
{[36]} \\
{[43]} \\
{[44]} \\
{[21]}\end{array}$ \\
\hline Upper-middle-income economies & China & {$[45,46]$} \\
\hline High-income economies & $\begin{array}{l}\text { Austria } \\
\text { Canada } \\
\text { Germany } \\
\text { Greece } \\
\text { Hong Kong } \\
\text { Italy } \\
\text { Japan } \\
\text { South Korea } \\
\text { Spain } \\
\text { The Netherlands } \\
\text { The UK } \\
\text { The US }\end{array}$ & $\begin{array}{l}{[47,48]} \\
{[49]} \\
{[50]} \\
{[51]} \\
{[30]} \\
{[52]} \\
{[50,53,54]} \\
{[55]} \\
{[56]} \\
{[53]} \\
{[57]} \\
{[19,58-63]}\end{array}$ \\
\hline
\end{tabular}

The lack of adequate knowledge among both adopters and nonadopters is a crucial barrier. Such lack of knowledge by adopters may result in improper usage and inability to maintain the systems, as shown in China. This may create a negative perception and prevent potential customers making a decision to adopt the systems [45]. In the case of Nicaragua, rural inhabitants know too little about PV systems, which can be one of the barriers for adoption [43]. It has also been shown in previous research that the diffusion of new technologies in rural communities requires more effort in tailoring the information and educating people [64]. In another case in the US, there is a lack of trust in the information that is widely and publicly available among some adopters. They feel uncertain about technology performance and lack information that is relevant to their individual cases [59]. A study in Austria [48] also revealed that lack of knowledge is not only a matter of adopter-side but also the supply-side. They argue that architects and planners often have insufficient knowledge about the advantages of building integrated PV systems. This is the reason why they do not offer such systems to the potential adopters when planning a new building.

The perception of adopters has a large impact on their decision whether to adopt a new technology or not. This is because the way that adopters perceive the complexity of technology can impact their decision on adoption $[65,66]$. Several studies investigated the diffusion process from the end-user's point of view. A study in the US showed that the residents were reluctant to adopt PV systems because of technology risk and complexity. These barriers are, however, reduced when third-party ownership is implemented [62]. For areas that are already connected to the grid, the perceived maintenance requirement can also be a barrier to adoption. In this

\footnotetext{
${ }^{3}$ In 2013, the World Bank categorized countries by GNI per capita. This income categorization is as follows: low income ( $\$ 1035$ or less), lower middle income (\$1036 to $\$ 4085)$ upper middle income (\$4086 to $\$ 12,615)$ and high income $(\$ 12,616$ or more) [35].
}

case, the customers have a choice to use electricity from the grid, which would not impose on them any responsibility to operate and maintain the technology, unlike having their own PV panels [61]. A survey study in China [46] indicated that the respondents perceive PV systems as having a low level of application. This can be related to the lack of technology awareness. Some users are also concerned about the complexity of the system, technological maturity, durability, efficiency, safety, and stability. In addition, there are some attributes of PV systems that are perceived negatively by the adopters. These are, for example, low battery storage and low power capacity.

Solar exposure is a basic requirement for functioning PV systems. Because the solar exposure depends on the geographic location, so does the competitiveness of PV systems. For example, the US energy portfolio varies across the country, making solar PV systems more technically feasible in some particular areas. This is due to large variation in climatic condition because the US covers a huge geographic area [19]. In the areas without other sources of electricity in Ethiopia, adopter's fear of non-functional systems during the rainy season is also a barrier preventing their purchase [10]. In some areas, PV systems face challenges from other competing technologies that are more suitable to their geography. A study in China mentioned that the increasing access to hydropower, as a means to provide electricity access in rural areas, has a negative influence on the adoption of SHS [45].

Society specific factors can also have an impact on the adoption. A comparative study between Kenya and Tanzania by Ondraczek [38] is an example of such a phenomenon. The lack of awareness among users and other stakeholders in Tanzania is one of the barriers to adoption. This lack of awareness is partly because of the geographical distance from big cities to rural villages, which makes firms less willing or unable to reach the market. Moreover, compared with the neighboring Kenyans, Tanzanians tend to be more reluctant and skeptical toward new technologies. The author further explained that education is another contributing factor, hindering the adoption of new technologies. Because of its socialist history, Tanzania is assumed to lack an entrepreneurial culture. There is also high complexity to doing business in Tanzania. In China [46], the lack of public awareness is apparent as a barrier to adoption. The Chinese are more aware of solar water-heater technology than solar PV technology. This affects their decision making on the adoption of PV systems in a negative way.

The architectural dimension of the areas is also an important factor that can become a barrier to adoption. For urban areas like Hong Kong, a key barrier is an inadequate installation space. PV panels need to be angled toward the right direction to maximize solar exposure. For rooftop integration in Hong Kong, the surface is simply too limited in old high-rise buildings. New buildings can, however, be designed to integrate PV systems in their structure to maximize the installation space [30]. The physical aspect of the city in terms of local building stock also has an impact on how much electricity can be generated from rooftop PV systems. In several Scottish cities, tenements are the preferred type of housing. The limited roof space on tenements results in less electricity output compared with the output from cities that have large properties. This is a limitation that is difficult to address by a policy mechanism [57].

In the case of Bolivia as studied by Pansera [42], the institutional dimension has been one of the key barriers for rural applications. Bolivia relies substantially on foreign financial aid. The country cannot easily design and execute renewable energy policy without international cooperation. However, despite the strong involvement, the international actors pose limitations. First of all, they lack the methodology to identify local needs. They also lack technical, human, and financial resources to tackle big 
projects in rural areas, which means that they are unable to achieve high impact. On the other hand, the private sector has little interest in this market. Missing a systematic vision of the local situation, these foreign actors want to implement one solution in all contexts, which is not possible. In several cases, the international counterparts also reveal political vested interests, e.g., establishing their products in a new market or acquiring privileged access to local natural resources. Moreover, local education, i.e., university research, is neglected, which prevents local capability building. In the case of Senegal studied by Thiam [44], the institutional dimension has also been identified as a barrier. Institutional reliability can encourage or discourage private sector involvement to create dynamics for them to utilize skills and knowledge in this market. The institutions also help increasing collaboration among related actors to work together to achieve larger diffusion. In Senegal, this is not yet the case.

Another barrier can arise from the applicability of PV technology to individual cases. One study conducted in Ghana showed that the capacities of the system are too high for the affordability of target adopters. Only high wattage systems are available in the market and they are sold only as a whole package. This is too costly for lowincome adopters [39]. In the lower-income markets, it has been shown that repackaging the products in small portions can facilitate the sale because it matches with their affordability [67].

Without demand, diffusion will be impeded. In some remote areas, lack of demand for electricity is a barrier to the adoption of PV systems. Here, we distinguish the reasons for the lack of demand into two types. First, it is due to the lack of electricity-related activities. In the low-income markets, some people have recently started to use household electrical appliances. For example, in the case of Tanzania, TV signals came rather late [38]. In Ethiopia, there are not many additional activities during night time that its inhabitants can do with the help of electricity access because most people are illiterate [10]. Second, it is due to the lack of customer base. In Tanzania, the market lacks customers from the rural middle and upper class who have purchasing power for PV systems and at the same time need electricity [38]. Without demand, the market cannot grow. In addition, lack of demand may arise from different demographic factors. Some studies showed that low education levels, which can be correlated with income level [40], and low purchasing power, which can be correlated with age groups [63], negatively influence the adoption of PV systems.

\subsection{Management barriers}

Insufficient and inappropriate management is one of the main barriers in the diffusion of new technology, not least for PV systems, especially when they are used in rural contexts.

One of the main management barriers is the inappropriate company business portfolio for the target market. When a PV system is utilized to supply electricity access in rural areas in low-income economies, different business strategies should be implemented (see e.g., $[21,36])$ compared with the high-income economies where it is often used as an alternative power supply. In addition, implementing similar business models as for urban usage is not applicable in rural settings because of several conditions that differentiate this market from the higher income adopters [67]. Appropriate financial schemes are required for the low-income markets. These are, for example, feefor-service and microcredit [36]. Financial schemes are important, as discussed in Section 3.3, and the companies should consider such schemes when entering the PV market. In addition, the study by Koinegg et al. [48] also showed that effective and appropriate business strategies are vital to prompt diffusion in particular markets. Based on building integrated PV market in Austria, they argue that lack of close collaboration between the building industry and the PV industry hindered take off in the market. This means that, unlike the conventional type of businesses in the PV industry, the system suppliers in building integrated PV sector need to develop a different type of business model that collaborates with more actors.

Weak and neglected after-sales service has also been shown to be a barrier to the diffusion of PV systems in rural areas. Because of the remoteness of the areas where PV systems are being used for rural electrification, the adopters lack access to information, knowledge, communication channels, technical assistance, and other infrastructure. This emphasizes the need for a functioning service to continue monitoring and maintenance, even after the customers have already bought the systems $[21,36]$. The need for this service, however, poses a challenge on cost and manpower to manage and guarantee the sustainability of the system $[42,45]$. In the case of Bolivia, rural inhabitants are very remote and relatively poor. When the systems are broken, they rather let them go instead of getting them repaired because this requires a lot of effort and money [42]. After-sales service models need further development to deal with the remoteness of the areas and the low-income level of rural adopters [45]. The problems with service can impair the quality of PV systems, which is another barrier to adoption as already discussed in the previous section.

Some other barriers are related to ineffective marketing approaches and education campaigns. For example, Ghanaian firms have not attempted to target the right customer group, i.e., affluent rural dwellers. While possessing sufficient affordability, these people do not have access to electricity. This strategy has been proven to be successful in Kenya and Zimbabwe. Establishing an early adopter customer base creates visibility that functions as a catalyst for diffusion in rural markets [39]. In Canada, Islam and Meade [49] argue that there should be education campaigns to communicate more information regarding the investment in PV systems, its environmental effect, and the feed-in-tariff. Otherwise, the barrier of low technology awareness cannot be overcome.

A national mechanism has an impact on the diffusion of technology. Existing national technical capacity and infrastructure can affect the diffusion of PV systems. This phenomenon is more evident among developing nations. In order to promote wide adoption, countries need to build technical capacity. In comparison with Kenya and Zimbabwe, Ghana has fewer PV companies and technicians. There are also fewer subsidiary institutions to support the PV industry, which impedes adoption of the technology [39]. In Tanzania, a national supply chain is difficult to undertake because of the inadequate transport infrastructure. This leaves remote areas underserved and the PV market concentrates around big cities [38]. A study comparing Japan and the Netherlands by Vasseur et al. [53] showed that Japan has a better technological innovation system to support the PV industry. In the Dutch case, there is a lack of collaboration and knowledge exchange between researchers and policy makers with adopters. The Dutch case also lacks human and financial resources to stimulate the PV market. Lastly, Thiam [44] argues that in the electricity market, fossil fuels are much more mature than PV technology. This prevents PV systems from being an attractive choice for customers. However, renewable energy tariffs that are set by the government can help in overcoming this immature market barrier. This national level of the barrier is highly associated with policy aspects that we discuss further in Section 3.4.

\subsection{Economic barriers}

The adoption of PV systems faces several economic barriers. These barriers can be in different forms, based on both time and location. As is known in the literature on innovations, the cost of an innovation usually decreases with time (e.g., [68]) and can vary depending on the location (e.g.,[69]). 
Economic barriers are usually related to the high cost of solar PV modules. The diffusion of PV systems is also affected by the cost of other energy sources in the region [19] because the potential adopters might have to choose between PV systems and conventional sources of energy. If the costs of competing sources are low, these can constitute a barrier to PV adoption. The lower the installation cost of PV systems, the more likely that people will adopt them. As a result, high costs for investment in PV systems are often perceived as a barrier to adoption, e.g., in China [46] and Japan [54]. The high costs of PV installation are mentioned in many studies that are based in several countries, such as South Korea, Greece, and the US [19,51,55,60]. Examples are spread over both off-grid, e.g., in Ethiopia [10] and Senegal [44] and on-grid applications, e.g., in Italy [52] and the US [61]. These discussions also include third-party owners [62]. In addition, the perception on the high cost of PV systems can vary. Koinegg et al. [48] argue that the perceived cost of PV systems can be a barrier to adoption. For building integrated PV systems, the cost is not necessarily as high as commonly perceived.

The study by Karteris and Papadopoulos [51] shows how the barriers can be bound to the particular local situation. Based on the Greek case under economic crisis, the authors mention the unwillingness of banks to fund medium- or long-term investments, including investments for PV systems. In addition, the shrinking economy results in reducing electricity demand and reducing interest in PV systems. A study in Ghana [39] also revealed the importance of the local context on understanding the barriers. The political instability in Ghana, which lasted over a period of several decades, resulted in turbulent economic growth. In 1966, the military government expelled most foreign nationals who worked in the retail business. This imposed insecurity for foreigners. The situation did not create an attractive environment for foreign direct investments in PV technology, preventing the fostering of PV systems in the Ghanaian market [39]. A study by Pansera [42] also emphasized the importance of the local situation. In rural areas of Bolivia, people cannot financially afford to fix the components of PV systems if needed. This means that the economic cost of maintenance of the PV technology can also be a barrier to the sustainability of adoption, especially because of poverty.

Based on the cases of off-grid systems in Kenya and Tanzania, Ondraczek [38] analyzed the residential SHS applications with a minor reference to other types such as small-scale commercial applications (including kiosk or mobile phone) and social institutions. In such a context, he conceptualized low purchasing power as a barrier to adoption. Based on several developing countries in Asia and Sub-Saharan Africa, Pode [36] emphasized economic affordability as a barrier to the diffusion of SHS in rural areas. The author incorporated this barrier in terms of high total cost, high up-front price, and payment inflexibility. In line with Pode [36], Lay et al. [40] identified the low income level of households to be a barrier for the adoption of SHS in Kenya. Moreover, a study by Komatsu et al. [37] indicated that income alone cannot explain the SHS adoption in Bangladesh. In this study, they emphasize that non-income factors can also be crucial for the households' decision making.

The study by Bawakyillenuo [39] focused on the diffusion of PV systems in Kenya and Zimbabwe and aimed to deduce policy recommendations for the Ghanaian case. As a synopsis of such a comparison, the lack of international donor funding for PV systems seems to be a barrier for diffusion to take off. In this manner, Palit [21] incorporated the lack of suitable financing mechanism as the most significant barrier, based on a comparative study of off-grid systems in several South Asian countries. In the case of Hong Kong for both on- and off-grid systems, Zhang et al. [30] also mentioned the high initial costs, high repair costs, and long payback period as barriers to adoption.
D’Agostino et al. [45] discussed China's Renewable Energy Development Project for SHS. They mention the inadequate government subsidy and the mismatch between consumer demand and certification program. In the case of off-grid systems in Nepal, Mainali and Silveira [41] discussed the large financial gap between the electrification cost and the level that people can afford. Such a mismatch can be perceived as a barrier. Brudermann et al. [47] discussed the on-grid applications of PV systems in Austrian agriculture. They identified two kinds of financial problems: the high investment needed for PV installation and uncertainties in the funding process.

\subsection{Policy barriers}

In conjunction with their high price, PV systems are usually not profitable without policy support in many countries. In this manner, policy measures are of vital importance for rapid diffusion of environmentally friendly innovations including PV systems (e.g., $[15,70])$.

At the moment, most countries have a variety of policy measures to support renewable energies. However, in some cases, existing policy support can be removed, causing a shock effect in the market. The case of Spain is one example of such a phenomenon. Movilla et al. [56] incorporated such a barrier when studying the Spanish case of diffusion of PV systems. In a similar manner for Austria, Brudermann et al. [47] also mentioned the negative impact of the reduction of subsidized feed-in tariffs on adoption.

Insufficient and ineffective policy support is often mentioned as a barrier in several studies in different contexts, e.g., in the Netherlands [53] and the US [58,63]. For example, Vasseur et al. [53] indicate the influence of inconsistent national subsidy schemes in the Netherlands, which can discourage entrepreneurs from investing in PV systems. In the South Korean case of microgeneration as studied by Jeong [55], policy support also exists but some potential adopters still do not want to install PV systems. This is because the benefits of adopting PV systems are not more than the costs. In this case, the potential adopters prefer direct subsidies instead of low-interest loans. Such a mismatch between demand and policy measures can also be observed in the case of some UK cities, where the policy measures do not correspond to the socioeconomic factors [57]. Huenteler et al. [50] analyzed market development paths in Japan and Germany and subsequently deduced policy recommendations for Japan. They argue that, for an effective renewable energy policy, the government should reduce the impact of industry interest on regulatory structure because it can impede the diffusion process. In this diverse discussion, they also mention three important barriers: non-institutionalizing on feed-in tariff revision, challenges on overcoming bureaucratic boundaries, and difficulties in establishing a well-coordinated policy mix. Such insufficient feed-in tariff schemes are also mentioned in the study by Karteris and Papadopoulos [51], which is based on on-grid systems in Greece. In the same manner, the type of policy is also crucial. For example, Sarzynski et al. [19] demonstrated that those states offering cash incentives as policy support experienced faster diffusion of gridtied PV technology than the states without cash incentives. With a strong focus on the solar renewable electricity certificate market, Gaul and Carley [60] analyzed the case of North Carolina in the US and deduced lessons from this case. They mention the lack of transparency in the certificates, which can be incorporated as a barrier to the adoption of PV systems. In another study [45], the negative influence of insufficient subsidies was also mentioned, highlighting the mismatch between consumer demand and certification program for SHS in China.

Three studies $[30,42,47]$ pay attention to the importance of cooperation and participation of the stakeholders in energy policy 
development. Based on the case of Hong Kong for both on- and off-grid systems, Zhang et al. [30] incorporated the lack of participation of stakeholders/community in energy policy planning and lack of incentives to support the adoption as important barriers. In the same manner, Brudermann et al. [47] emphasized the negative effects of non-cooperative building experts, issues with building permits, and the decision process in regional governments, which takes too much time for grant notification. In addition, Pansera [42] conceptualized the lack of innovation policy strategy as a barrier in Bolivia and suggested a better coordination between stakeholders at the national level.

Although some policies in low-income economies target offgrid applications, some potential adopters still prefer to wait for the grid extension rather than adopting off-grid PV systems. This means that adopter's future expectations can become a barrier in some cases. This was observed by Bawakyillenuo [39], who analyzed the case of Ghana in comparison with Kenya and Zimbabwe. However, Lay et al. [40] found that grid extension does not necessarily prevent the adoption of SHS in Kenya. This is because SHS can be sometimes considered as a complementary energy source.

In some cases, policy support for other sources of energy production can be a barrier to the adoption of PV systems. An example of such a phenomenon can be seen in the study by Blum et al. [12]. In this study, they analyzed the cost competitiveness of renewable energy technologies in Indonesia, mentioning that fossil fuel subsidies make a PV system less competitive. As a consequence, there is a lack of private investment in the PV sector.

\section{Conclusions}

Even though several studies argue that PV systems are becoming mature enough to compete with other conventional energy sources (e.g., [71,72]), our study reveals that the diffusion and adoption of PV systems still face several barriers. Based on an extensive and systematic state-of-the-art literature review, we have shown that the barriers are evident for both low- and highincome economies, e.g., among others, Austria, Bangladesh, China, Nicaragua, the Netherlands, and the US. Although the barriers should be evaluated in a particular context, e.g., in regard to a country or a type of grid connection, the barriers commonly constitute four interrelated dimensions: sociotechnical, management, economic, and policy.

The overall result of this study implies that the adoption of PV systems-either as a substitute for other electricity power generation systems in urban areas or for rural electrification-is still a challenging process. From the economic point of view, the cost of PV systems is still generally perceived as high. In regard to the sociotechnical dimension, several studies imply that the complexity of interaction between people and PV systems can hinder the adoption. In addition, there are still several barriers related to the policy dimension and technology management. Ineffective policy measures and inappropriate management can hamper the diffusion process in a variety of contexts.

Our findings have several practical implications. For the wide adoption of PV systems, the literature discussed in this review paper suggests that the involvement of all stakeholders-adopters, local communities, firms, international organizations, financial institutions, and government-is still crucial. Without proper collaboration, effective marketing, and dedicated government support, the barriers to adoption will not be easily overcome. However, technology diffusion is context specific and so is the adoption of PV systems. Therefore, all stakeholders should understand the local conditions of the particular context in order to overcome the barriers.
As far as research implications are concerned, this study provides a novel contribution by synthesizing the state-of-theart barriers to the adoption of PV systems. By outlining the barriers from a variety of contexts in detail, we provide a comprehensive perspective for researchers studying the barriers. Although the barriers can vary across contexts, the lessons from one study can be valuable for others.

\section{Acknowledgments}

This research was partially funded by KTH Royal Institute of Technology, a Royal Thai Government Scholarship and a European Doctorate in Industrial Management (EDIM) fellowship. EDIM is a part of Erasmus Mundus Action 1 programs, financed by the Education, Audiovisual and Culture Executive Agency (EACEA) of the European Commission (Specific Grant Agreement, SGA: 20111531).

\section{References}

[1] Smil V. Energy transitions: history, requirements, prospects. Santa Barbara, CA: Praeger Publishers; 2010

[2] IEA. World energy outlook 2012. International Energy Agency (IEA); 2012.

[3] EPIA. Market report 2013. European Photovoltaic Industry Association (EPIA); 2014.

[4] IEA. PVPS Report Snapshot of Global PV 1992-2013. Int Energy Agency 2014:1-16.

[5] Baanabe J. Energy supply in Uganda, Ministry of Energy and Mineral Development 2012. 〈http://www.unep.org/transport/pcfv/PDF/icct_2012/ICCT_Ener gySituation_JamesBanaabe_MEMD.pdf) (accessed 26.04.15).

[6] Meza E. Bangladesh installs 3 million residential solar systems. PV Mag 2014. 〈http://www.pv-magazine.com/news/details/beitrag/bangladesh-installs-3million-residential-solar-systems_100017123/\#axzz3YUKdsqP5) (accessed: 12.11.14).

[7] Katzman T. Paradoxes in the diffusion of a rapidly advancing technology: the case of solar photovoltaics. Technol Forecast Soc Change 1981;19:227-36.

[8] Mesak H, Coleman R. Modeling the effect of subsidized pricing policy on new product diffusion. Omega 1992;20:303-12. http://dx.doi.org/10.1016/03050483(92)90035-6.

[9] Jacobsson S, Johnson A. The diffusion of renewable energy technology: an analytical framework and key issues for research. Energy Policy 2000;28:625-40.

[10] Müggenburg H, Tillmans A, Schweizer-Ries P, Raabe T, Adelmann P. Social acceptance of PicoPV systems as a means of rural electrification-A sociotechnical case study in Ethiopia. Energy Sustain Dev 2012;16:90-7. http://dx. doi.org/10.1016/j.esd.2011.10.001.

[11] Dewald U, Truffer B. Market formation in technological innovation systemsdiffusion of photovoltaic applications in Germany. Ind Innov 2011;18:285-300. http://dx.doi.org/10.1080/13662716.2011.561028.

[12] Blum NU, Sryantoro Wakeling R, Schmidt TS. Rural electrification through village grids-assessing the cost competitiveness of isolated renewable energy technologies in Indonesia. Renew Sustain Energy Rev 2013;22:482-96. http: //dx.doi.org/10.1016/j.rser.2013.01.049.

[13] Lund PD. Boosting new renewable technologies towards grid parity-economic and policy aspects. Renew Energy 2011;36:2776-84. http://dx.doi.org/ 10.1016/j.renene.2011.04.025

[14] Sriwannawit P, Claise G, Phdungsilp A, Howells M. The effect of policy on photovoltaic competitiveness: analysis on household on-grid application in rural Thailand. In: Proceedings of the 9th conference on Sustainable Development of Energy, Water and Environment Systems, Venice-Istanbul; 2014.

[15] Jacobsson S, Lauber V. The politics and policy of energy system transformationexplaining the German diffusion of renewable energy technology. Energy Policy 2006;34:256-76. http://dx.doi.org/10.1016/j.enpol.2004.08.029.

[16] Fabrizio KR, Hawn O. Enabling diffusion: how complementary inputs moderate the response to environmental policy. Res Policy 2013;42:1099-111. http: //dx.doi.org/10.1016/j.respol.2013.02.003.

[17] Sriwannawit P, Laestadius S. Diffusion of photovoltaic systems for rural electrification in Thailand. Int J Energy Environ 2013;4:49-58.

[18] Mulugetta Y, Nhete T, Jackson T. Photovoltaics in Zimbabwe: lessons from the GEF Solar project. Energy Policy 2000;28:1069-80. http://dx.doi.org/10.1016/ S0301-4215(00)00093-8.

[19] Sarzynski A, Larrieu J, Shrimali G. The impact of state financial incentives on market deployment of solar technology. Energy Policy 2012;46:550-7. http: //dx.doi.org/10.1016/j.enpol.2012.04.032.

[20] Karakaya E, Hidalgo A, Nuur C. Motivators for adoption of photovoltaic systems at grid parity: a case study from Southern Germany. Renew Sustain Energy Rev 2015;43:1090-8. http://dx.doi.org/10.1016/j.rser.2014.11.077. 
[21] Palit D. Solar energy programs for rural electrification: experiences and lessons from South Asia. Energy Sustain Dev 2013;17:270-9. http://dx.doi. org/10.1016/j.esd.2013.01.002.

[22] Sriwannawit P. Transition towards off-grid photovoltaic systems: is price the final answer? Energy Procedia 2014;57:1546-54. http://dx.doi.org/10.1016/j. egypro.2014.10.146.

[23] Dorf R. Managerial and economic barriers and incentives to the commercialization of solar energy technologies. Eng Manag Int 1984;2:17-31.

[24] NREL. Best research-cell efficiences. Natl Reneable Energy Lab 2014. 〈http:// www.nrel.gov/ncpv/images/efficiency_chart.jpg (accessed: June 10.06.14).

[25] FT. Renewables: a rising power. Financ Times; 2013, p. 9-12 (08.08.13).

[26] Ren21. Renewables 2013: global status report. renewable energy policy network for the 21st centruy (Ren21); 2014.

[27] Walker H, Di Sisto L, McBain D. Drivers and barriers to environmental supply chain management practices: lessons from the public and private sectors. J Purch Supply Manag 2008;14:69-85. http://dx.doi.org/10.1016/j.pursup.2008.01.007.

[28] Boonstra A, Broekhuis M. Barriers to the acceptance of electronic medical records by physicians from systematic review to taxonomy and interventions. BMC. Health Serv Res 2010;10:231. http://dx.doi.org/10.1186/1472-6963-10231.

[29] Mondal MAH, Kamp LM, Drivers Pachova NI. barriers, and strategies for implementation of renewable energy technologies in rural areas in Bangladesh-an innovation system analysis. Energy Policy 2010;38:4626-34. http: //dx.doi.org/10.1016/j.enpol.2010.04.018.

[30] Zhang X, Shen L, Chan SY. The diffusion of solar energy use in HK: what are the barriers? Energy Policy 2012;41:241-9. http://dx.doi.org/10.1016/j. enpol.2011.10.043.

[31] Sriwannawit P, Sandström U. Large-scale bibliometric review of diffusion research. Scientometrics 2015;102:1615-45. http://dx.doi.org/10.1007/s11192014-1448-7.

[32] Crossan MM, Apaydin M. A multi-dimensional framework of organizational innovation: a systematic review of the literature. J Manag Stud 2010;47:1154-91. http://dx.doi.org/10.1111/j.1467-6486.2009.00880.x.

[33] Karakaya E, Hidalgo A, Nuur C. Diffusion of eco-innovations: a review. Renew Sustain Energy Rev 2014:33:392-9.

[34] Rogers EM. Diffusion of innovations. 5th ed.. New York: The Free Press; 2003.

[35] WB. World Bank categorization of countries by income. World Bank 2014. 〈http://data.worldbank.org/about/country-classifications/country-and-le nding-groups $>$ (accessed: 06.05.14).

[36] Pode R. Financing LED solar home systems in developing countries. Renew Sustain Energy Rev 2013;25:596-629. http://dx.doi.org/10.1016/j.rser.2013.04.004.

[37] Komatsu S, Kaneko S, Shrestha RM, Ghosh PP. Nonincome factors behind the purchase decisions of solar home systems in rural Bangladesh. Energy Sustain Dev 2011;15:284-92. http://dx.doi.org/10.1016/j.esd.2011.03.003.

[38] Ondraczek J. The sun rises in the east (of Africa): a comparison of the development and status of solar energy markets in Kenya and Tanzania. Energy Policy 2013;56:407-17. http://dx.doi.org/10.1016/j.enpol.2013.01.007.

[39] Bawakyillenuo S. Deconstructing the dichotomies of solar photovoltaic (PV) dissemination trajectories in Ghana, Kenya and Zimbabwe from the 1960s to 2007. Energy Policy 2012;49:410-21. http://dx.doi.org/10.1016/j.enpol.2012.06.042.

[40] Lay J, Ondraczek J, Stoever J. Renewables in the energy transition: evidence on solar home systems and lighting fuel choice in Kenya. Energy Econ 2013;40:350-9. http://dx.doi.org/10.1016/j.eneco.2013.07.024.

[41] Mainali B, Silveira S. Financing off-grid rural electrification: country case Nepal. Energy 2011;36:2194-201. http://dx.doi.org/10.1016/j.energy.2010.07.004.

[42] Pansera M. Renewable energy for rural areas of Bolivia. Renew Sustain Energy Rev 2012;16:6694-704. http://dx.doi.org/10.1016/j.rser.2012.08.015.

[43] Rebane KL, Barham BL. Knowledge and adoption of solar home systems in rural Nicaragua. Energy Policy 2011;39:3064-75. http://dx.doi.org/10.1016/j. enpol.2011.02.005.

[44] Thiam DR. An energy pricing scheme for the diffusion of decentralized renewable technology investment in developing countries. Energy Policy 2011;39:4284-97. http://dx.doi.org/10.1016/j.enpol.2011.04.046.

[45] D'Agostino AL, Sovacool BK, Bambawale MJ. And then what happened? A retrospective appraisal of China's renewable energy development project (REDP) Renew Energy 2011;36:3154-65. http://dx.doi.org/10.1016/j. renene.2011.03.017.

[46] Yuan X, Zuo J, Ma C. Social acceptance of solar energy technologies in Chinaend users' perspective. Energy Policy 2011;39:1031-6. http://dx.doi.org/ 10.1016/j.enpol.2011.01.003.

[47] Brudermann T, Reinsberger K, Orthofer A, Kislinger M, Posch A. Photovoltaics in agriculture: a case study on decision making of farmers. Energy Policy 2013;61:96-103. http://dx.doi.org/10.1016/j.enpol.2013.06.081.
[48] Koinegg J, Brudermann T, Posch A, Mrotzek M. It would be a shame if we did not take advantage of the spirit of the times. An analysis of prospects and barriers of building integrated photovoltaics. Ecol Perspect Sci Soc 2013;22:39-45.

[49] Islam T, Meade N. The impact of attribute preferences on adoption timing: the case of photo-voltaic (PV) solar cells for household electricity generation. Energy Policy 2013;55:521-30. http://dx.doi.org/10.1016/j.enpol.2012.12.041.

[50] Huenteler J, Schmidt TS, Kanie N. Japan's post-Fukushima challenge-implications from the German experience on renewable energy policy. Energy Policy 2012;45:6-11. http://dx.doi.org/10.1016/j.enpol.2012.02.041.

[51] Karteris M, Papadopoulos AM. Legislative framework for photovoltaics in Greece: a review of the sector's development. Energy Policy 2013;55:296-304. http://dx.doi.org/10.1016/j.enpol.2012.12.001.

[52] Ameli N, Kammen DM. Clean energy deployment: addressing financing cost Environ Res Lett 2012;7:034008. http://dx.doi.org/10.1088/1748-9326/7/3/ 034008.

[53] Vasseur V, Kamp LM, Negro SO. A comparative analysis of photovoltaic technological innovation systems including international dimensions: the cases of japan and the Netherlands. J Clean Prod 2013;48:200-10. http://dx. doi.org/10.1016/j.jclepro.2013.01.017.

[54] Zhang Y, Song J, Hamori S. Impact of subsidy policies on diffusion of photovoltaic power generation. Energy Policy 2011;39:1958-64. http://dx. doi.org/10.1016/j.enpol.2011.01.021.

[55] Jeong G. Assessment of government support for the household adoption of micro-generation systems in Korea. Energy Policy 2013;62:573-81. http://dx. doi.org/10.1016/j.enpol.2013.07.015.

[56] Movilla S, Miguel LJ, Blázquez LF. A system dynamics approach for the photovoltaic energy market in Spain. Energy Policy 2013;60:142-54. http: //dx.doi.org/10.1016/j.enpol.2013.04.072.

[57] Gooding J, Edwards H, Giesekam J, Crook R. Solar city indicator: a methodology to predict city level PV installed capacity by combining physical capacity and socio-economic factors. Sol Energy 2013;95:325-35. http://dx.doi.org 10.1016/j.solener.2013.06.027.

[58] Zhai P. Analyzing solar energy policies using a three-tier model: a case study of photovoltaics adoption in Arizona, United States. Renew Energy 2013;57:317-22. http://dx.doi.org/10.1016/j.renene.2013.01.058.

[59] Rai V, Robinson SA. Effective information channels for reducing costs of environmentally-friendly technologies: evidence from residential PV markets. Environ Res Lett 2013;8:014044. http://dx.doi.org/10.1088/1748-9326/8/1/ 014044.

[60] Gaul C, Carley S. Solar set asides and renewable electricity certificates: early lessons from North Carolina's experience with its renewable portfolio standard. Energy Policy 2012;48:460-9. http://dx.doi.org/10.1016/j.enpol.2012.05.043.

[61] Zhai P, Williams ED. Analyzing consumer acceptance of photovoltaics (PV) using fuzzy logic model. Renew Energy 2012;41:350-7. http://dx.doi.org/ 10.1016/j.renene.2011.11.041.

[62] Drury E, Miller M, Macal CM, Graziano DJ, Heimiller D, Ozik J, et al. The transformation of southern California's residential photovoltaics market through third-party ownership. Energy Policy 2012;42:681-90. http://dx.doi. org/10.1016/j.enpol.2011.12.047.

[63] Kwan CL. Influence of local environmental, social, economic and politica variables on the spatial distribution of residential solar PV arrays across the United States. Energy Policy 2012;47:332-44. http://dx.doi.org/10.1016/j. enpol.2012.04.074

[64] Sriwannawit P. Managing the diffusion of electrification in Bangladesh. International Conference on Management of Technology, Taiwan, 2012.

[65] Venkatesh V. Determinants of perceived ease of use: Integrating control intrinsic motivation, and emotion into the technology acceptance model. Inf Syst Res 2000;1997:342-65.

[66] Davis F. Perceived usefulness, perceived ease of use, and user acceptance of information technology. MIS Q 1989;13:319-40.

[67] Prahalad CK. The fortune at the bottom of the pyramid: Eradicating poverty through profits (revised and updated 5th anniversary edition). Upper Saddle River, New Jersey: Pearson Education, Inc.; 2010.

[68] Spence A. The learning curve and competition. Bell J Econ 1981;12:49-70.

[69] Karakaya E, Nuur C, Breitschopf B, Hidalgo A. Spatial dimension of lead markets: evidences from diffusion of photovoltaic systems in Germany. DRUID society confernce, CBS, Copenhagen; 2014 (June 16-18, 2014).

[70] Rennings K. Redefining innovation-eco-innovation research and the contribution from ecological economics. Ecol Econ 2000;32:319-32.

[71] Lettner G, Auer H. Realistic roadmap to PV grid parity for all target countries Vienna Univ Technol-PV Parit Proj 2012

[72] Pérez D, Cervantes V, Báez MJ, Domínguez FT. PV grid parity monitor residential sector. Spain Eclareon 2013. 